\title{
QUALITY ASSURANCE OF MEDICINES: THE STATE AND TRENDS OF THE EUROPEAN UNION AND UKRAINE LEGISLATION DEVELOPMENT
}

\author{
Lidiia H. Yurkovska, Volodymyr V. Krasnov, Serhii H. Ubohov \\ SHUPYK NATIONAL MEDICAL ACADEMY OF POSTGRADUATE EDUCATION, MINISTRY OF HEALTH OF UKRAINE, KYIV, UKRAINE
}

\begin{abstract}
The aim: Scientific substantiation of the state and tendencies of development at the present stage of the legislation of the European Union and Ukrainian legislation on quality assurance of medicines.

Materials and methods: Using the biblio-semantic, systematic-review, analytical, formal-legal and comparative-law methods, the individual regulatory sources of pharmaceutical legislation of the EU and Ukraine were studied.

Conclusions: The paper identifies that pharmaceutical legislation of the EU and Ukraine on quality assurance of medicines at the present stage of their development have common features, which include the number, disorder of existing legal acts, which creates conflicts between them and the potential for gaps in regulation. The main trend in the development of this legislation in the EU and Ukraine is the disparity of legal acts and the lack of significant legislative efforts to codify them.
\end{abstract}

KEY WORDS: quality of medicines, quality assurance, EU pharmaceutical legislation, Ukrainian pharmaceutical legislation

\section{INTRODUCTION}

The pharmaceutical sector in the healthcare sector of Ukraine is constantly looking for the best ways to integrate into the European and international space. This requires, among other things, continuous efforts to harmonize the pharmaceutical legislation of Ukraine on quality assurance of medicines with the regulatory requirements of international and European legal acts. These processes of harmonization of domestic legislation with international or regional legal sources are not easy for any country, including Ukraine. The reasons for the difficulties are, in particular, the specific features and trends of development of both Ukrainian pharmaceutical legislation and international (regional European) legal sources.

In Ukraine, various aspects of pharmaceutical law have been investigated by pharmacists [1-4], legal scholars [5-8] and representatives of other scientific fields [9] in different years. However, the current peculiarities and tendencies of the development of legislation on quality assurance of medicines at the regional European and national Ukrainian level require additional scientific attention. Scientific interest in these issues is also substantiated by the fact that Ukraine at the level of its Constitution has determined the irreversibility of the European and Euro-Atlantic course, the strategic course of the country for the acquisition of full membership of Ukraine in the European Union and in the Organization of the North Atlantic Treaty [10]. The course set out in the Consti- tution of Ukraine together with the provisions of the Association Agreement between Ukraine, of the one part, and the European Union, the European Atomic Energy Community and their Member States, of the other part (hereinafter - the Association Agreement) [11] secondly, the task of harmonizing Ukrainian and EU legislation. This creates the legal basis for modern processes of harmonization of the pharmaceutical legislation of Ukraine with the relevant EU regulatory sources, including the quality assurance of medicines.

\section{THE AIM}

The aim of the work is to substantiate the current state and trends of development at the current stage of European Union legislation and Ukrainian legislation on quality assurance of medicines in the context of harmonization of European Union and Ukrainian legislation on quality assurance of medicines.

\section{MATERIALS AND METHODS}

Using biblio-semantic, systematic-review, analytical, formal-legal and comparative-legal methods, scientific elaboration of separate regulatory sources of pharmaceutical legislation of the EU and Ukraine, which determine the legal basis for quality assurance of medicines at the main stages of their life cycle, was carried out. 


\section{REVIEW}

The evolution of EU pharmaceutical law is driven by the integration tendencies of creating a common internal market in European countries, including the market for medicines with corresponding positive economic effects for medicines developers and manufacturers, their distributors and end-users. In addition, a significant impact on the development of EU pharmaceutical legislation was made by the ongoing search for the best ways to address the fundamental challenges of increasing the level of social protection, raising the standard of living and quality of life of the countries that initially joined the European Economic Community and later the EU.

Since the 1960s, as a result of regional European and global harmonization of pharmaceutical law, the rules for preclinical study and clinical testing of new medicines, their procedure for registration, ICH and RIS / S recommendations, GLP, GCP, GMP, GDP, GPP, GVP, industry inspection system, etc. In recent years, harmonization has spread to the wholesale and retail of medicines, advertising, quality control organizations. The program of medicinal substance international names choice, methods of efficacy and safety evaluation of medicines, harmonized approaches to quality assurance, principles of marketing promotion have been successfully used [9].

One of the central legal sources of modern EU pharmaceutical legislation is Directive 2001/83 / EC of the European Parliament and of the Council of 6 November 2001 on the Community code relating to medicinal products for human use [12]. However, this source applies along with many other directives, regulations, decisions of EU governing bodies, such as: Directive No 2001/20/EC of the European Parliament and of the Council of 4 April 2001 on the approximation of the laws, regulations and administrative provisions of the Member States relating to the implementation of good clinical practice in the conduct of clinical trials on medicinal products for human use; Commission Directive No 2003/94/ EC of 8 October 2003 laying down the principles and guidelines of good manufacturing practice in respect of medicinal products for human use and investigational medicinal products for human use; Regulation (EC) No 1394/2007 of the European Parliament and of the Council of 13 November 2007 on advanced therapy medicinal products and amending Directive 2001/83/EC and Regulation (EC) No 726/2004; Regulation (EC) No 141/2000 of the European Parliament and of the Council of 16 December 1999 on orphan medicinal products; Regulation (EC) No 1901/2006 of the European Parliament and of the Council of 12 December 2006 on medicinal products for paediatric use and amending Regulation (EEC) No 1768/92, Directive 2001/20/EC, Directive 2001/83/EC and Regulation (EC) No 726/2004; Regulation (EC) No 726/2004 of the European Parliament and of the Council of 31 March 2004 laying down Community procedures for the authorisation and supervision of medicinal products for human and veterinary use and establishing a European Medicines Agency etc. [5].

A study of the texts of these and other sources of EU pharmaceutical law has shown that the legal rules governing the quality assurance of medicinal products in the $\mathrm{EU}$ are not, at present, merged into one single systematic source, but scattered across different legal acts that form the totality of EU pharmaceutical legislation. For example, the terminological analysis of the text of Directive 2001/83 / EC of 6 November 2001 showed that the expression «quality of medicines» in different variants of terms is used 13 times in different parts of this legal act.

The analysis of not only this European source, but also of other acts, including international acts, indicates a similar approach of the drafters of legal sources to the definition of the legal bases for quality assurance of medicines. Relevant legal provisions are set out in international and regional legal acts, whose call is, first of all, to regulate the legal relations and the legal regime of medicines in general or of certain types of medicines at a certain stage of their life cycle.

This is typical of the GxP guidance system. For example, Good Pharmacy Practice (GPP), which defines the requirements for the retail medicines phase, contains only one mention of the term "medicines quality». However, this provision is crucial because it requires states at national or, where appropriate (for example, at state or provincial level) to establish a legal structure that, among other things, ensures the integrity of the supply chain and the quality of medicines [13].

Thus, at present, a considerable number of legal provisions defining the requirements for quality assurance of medicines at all stages of their life cycle have been accumulated in sources of EU law and pharmaceutical law, which belong to different types of legal sources and have been approved in different years. The main tendency of the legal ordering of the quality of medicines is to preserve the dispersion of the relevant norms by different legal sources and the absence of significant law-making efforts to systematize them in any way in one or more legal acts.

Iven that Ukraine is not yet a member of the EU, Union rules do not apply automatically in Ukraine. Typical decisions in the EU and Ukraine so far, such as the approval of medicines for their introduction into production, their admission to the market and the prevention of risks to patient and public health, are made in different regulatory environments and under different procedures. The competent authority of Ukraine may not participate in a decentralized or mutual recognition procedure for medicines introduced in the EU. To address these and other issues, national legislation should be harmonized with EU law in accordance with the Association Agreement and its annexes [5].

The one of the central terminological constructions in Ukraine that characterizes pharmaceutical relationships at all stages of the medicines life cycle and, accordingly, is reflected in a number of regulatory acts (RAs) is "quality assurance of medicines". On January 23, 2020, we searched the official web portal of the Verkhovna Rada of Ukraine for a search for "quality assurance of medicines», which obtained a list of 694 documents. The request was formed with definitions of the status of the document as «valid» 
Table I. Number of approved and valid RAs in Ukraine by time periods

\begin{tabular}{ccc}
\hline Time period, years & $\begin{array}{c}\text { Number of approved RAs that have remained } \\
\text { in force as of } \mathbf{2 3 / 0 1 / 2 0 2 0}\end{array}$ & $\begin{array}{c}\text { The average annual number of approved RAs that } \\
\text { has remained in force as of 23/01/2020 }\end{array}$ \\
\hline $2010-2019$ & 478 & 48 \\
\hline $2000-2009$ & 182 & 18 \\
\hline $1991-1999$ & 29 & 3 \\
\hline $1991-2019$ & $\mathbf{6 8 9}$ & $\mathbf{2 4}$ \\
\hline Before 1991 & 5 & - \\
\hline Before 1991-2019 & $\mathbf{6 9 4}$ & - \\
\hline
\end{tabular}

Table II. Number of approved and valid NPAs in Ukraine by their publishers as of 23/01/2020

\begin{tabular}{ccc}
\hline № & Document publisher & Number of published documents \\
\hline 1. & Verkhovna Rada of Ukraine (Supreme Council) & 140 \\
\hline 1.1. & Verkhovna rada of USSR (before 24.08.1991) & 5 \\
\hline 2. & President of Ukraine & 12 \\
\hline 3. & National Security and Defense Council of Ukraine & 2 \\
\hline 4. & Cabinet of Ministers of Ukraine & 209 \\
\hline 5. & Ministry of Health of Ukraine & 157 \\
\hline 6. & Other Ministries & 147 \\
\hline 7. & Other Authorities & 22 \\
\hline & TOTAL: & 694 \\
\hline
\end{tabular}

and with search of the given terminological construction both in the title and in the text of the documents.

Important features that were able to be established by analyzing the received list of documents is a significant increase in the attention of the regulatory authorities of Ukraine over the last decade to the legal regulation of pharmaceutical relationships. As the Association Agreement between Ukraine and the EU requires the harmonization of the pharmaceutical legislation of Ukraine and the legislation of the EU, this has become one of the key factors in the intensification of law-making processes by both the Parliament of Ukraine and the regulatory bodies of the executive power.

According to Table I, over the past 10 years (2010 2019), 478 RAs have been adopted, and in the previous 19 years (1991 - 2009), 211 RAs have been addressed to the quality of medicines. Currently, only 5 RAs that have been approved until 1991 and contain references to quality assurance have remained in force.

Table II provides information on the number of RAs approved by various Ukrainian authorities. The given number of legal sources includes not only acts developed by state bodies of Ukraine, but also ratified by Ukraine interstate agreements and documents of international organizations. The latter include the United Nations, the World Health Organization, the International Labor Organization, the International Bank for Reconstruction and Development, the European Community and the European Union, the Council of Europe, the European Free Trade Association, etc.

One of the key legal sources for determining the principles of medicines circulation in Ukraine is the Law on
Medicines of Ukraine [14]. Along with this it is noteworthy that among the studied RAs there are 122 Laws of Ukraine and 297 orders of the central executive bodies of Ukraine. The aforementioned testifies to the significant dispersion, disorder of the current RAs of Ukraine, which mentions the quality assurance of medicines. They are approved in different years, by different bodies and, of course, are based on different conceptual bases, contain different approaches to the use of terminology, legal constructs, sequence of presentation of legal material, etc. It is quite natural that among such a significant but still not systematic array of legislation there are conflicts of both hierarchical and temporal nature, as well as gaps in the ordering of those legal phenomena and processes that evolve through the practice of ensuring the quality of medicines at different stages. their life cycle.

\section{DISCUSSION}

In writing this work, we are aware that along with the terminological constructs "quality of medicines" or "quality assurance of medicines", related and relevant terms are used in the texts of international, European and Ukrainian pharmaceutical legislation, including "safety of medicines", "efficacy of medicines", "suitability of medicines" and the like.

In our opinion, these terms indicate particular aspects of medicines quality and are integral parts of it. The quality of medicines is a generic (integrated) concept that covers the safety of medicines for all interested parties, and the ability of medicines to satisfy the immediate interests of end users, and compliance of medicines with the requirements set out in the legislation and technical documentation [2]. Therefore, the use 
of the generic and key constructions «quality of medicines» and «quality assurance of medicines» for the terminological analysis of the legislative arrays of EU and Ukrainian pharmaceutical law is considered quite reasonable.

According to the results of the research, a significant number of disordered, but current RAs always poses a risk to stakeholders who implement their legal requirements in practice. The risk is not only in the inconvenience of using such a large array of RAs created by international and European institutions, as well as by state bodies of Ukraine, but, above all, in the possibility of interested parties violating the contradictory requirements of current legislation. However, such violations are not committed in the form of deliberate actions with predetermined unlawful intentions, but because of an unintentional, erroneous omission of the requirements of a particular RA. As a general rule, such violations provide for more lenient sanctions than for intentional offenses, but the infringing entity is still subject to negative legal liability. As you know, ignorance of the law does not release from responsibility for its violation.

Over the last almost 20 years, Ukrainian scientists have repeatedly put forward initiatives to codify the medical and pharmaceutical legislation of Ukraine $[3,5,15]$, but the level of doctrinal projects and proposals has not gone well. Unfortunately, at present there is no work on codification or other systematization of medical or pharmaceutical legislation in the focus of attention of the Verkhovna Rada of Ukraine (the only legislative body of Ukraine [10]).

At the present stage, Ukraine is facing quite difficult tasks that are currently underway to harmonize its own non-consolidated, non-codified array of pharmaceutical legislation with EU law, which is also far enough from being systematically in the classical sense of the concept, due to the regularity of formation and development of continents legal family.

\section{CONCLUSIONS}

Thus, pharmaceutical legislation of the EU and Ukraine on quality assurance of medicines at the present stage of their development, despite the considerable number of substantive and formal differences, is characterized by the following common features: the number and disorder of existing RAs of different legal force, approved in different years and by different regulatory authorities, which gives rise to temporal and hierarchical conflicts of data in the RA, as well as gaps in the regulation of certain aspects of pharmaceutical relationships. The main tendency for the development of this legislation in the EU and Ukraine is to maintain the fragmentation of the RAs and the absence of significant legislative efforts to codify them. These legislative features and the tendency to preserve them significantly complicate and delay in time the processes of harmonization of domestic pharmaceutical legislation with EU legislation, create obstacles to the proper legal regulation of the pharmaceutical sector, and also require overcoming, which is the main way we see in the efforts of the systematic or systematic legal framework both in the EU and in Ukraine. This will be the subject of our further research.

\section{REFERENCES}

1. Kotvitska A. et al. Osnovy prava ta zakonodavstva u farmatsii [Fundamentals of Law and Legislation in pharmacy] : nats. pidruch. dlia studentiv vyshch. navch. Zakl. Nats. farmatsevt. un-t MOZ Ukrainy. Kharkiv : Zoloti storinky. 2016: 528. (In Ukrainian).

2. Vetiutnea N. et al. Suchasna kontseptsiia zabezpechennia yakosti likarskykh zasobiv [Modern concept of quality assurance of medicines]: kolektyvna .Nilan-LTD. 2018: 400. (In Ukrainian).

3. Soloviov 0.S. Naukovo-praktychne ta teoretychne obgruntuvannia systemy zakhodiv zabezpechennia farmatsevtychnoho prava u sferi obihu, promotsii likarskykh zasobiv i parafarmatsevtychnoi produktsii [Scientific, practical and theoretical substantiation of the system of measures of ensuring pharmaceutical law in the sphere of circulation, promotion of medicines and parapharmaceutical products]. . Kharkiv. 2018: 619. (In Ukrainian).

4. Vetiutneva N.O., Ubohov S.H., Budnikova T.M. et al. Normatyvnopravove rehuliuvannia u sferi zabezpechennia yakosti likarskykh zasobiv v Ukraini: retrospektyvnyi analiz [Legal regulation in the field of quality assurance of medicines in Ukraine: a retrospective analysis]. Farmatsevtychnyi zhurnal. 2013; 4: 9-18. (In Ukrainian

5. Pashkov V. M. Pravove zabezpechennia implementatsii zakonodavstva YeS shchodo obihu likarskykh zasobiv. [Legal support for the implementation of EU legislation on the circulation of medicines]. Medical Law. 2016; 2(18): 55-62. (In Ukrainian

6. Pasechnyk 0. V. Intehratsiino-pravove rehuliuvannia obihu likarskykh zasobiv u Yevropeiskomu Soiuzi [Integrative regulation of the circulation of medicines in the European Union]. Odesa. 2015: 238. (In Ukrainian).

7. Demchenko I. S. Vplyv Uhody pro asotsiatsiiu na podalshyi rozvytok medychnoho prava v Ukraini [The impact of the Association Agreement on the further development of medical law in Ukraine]. Pravo i Hromadianske Suspilstvo. 2014; 1:221-231. (In Ukrainian).

8. Vasyliev S. Normatyvno-pravove rehuliuvannia rozdribnoi torhivli likarskymy zasobamy [Legal regulation of the retail trade of medicines]. Pidpryiemnytstvo, Hospodarstvo i Pravo. 2018; 1:41-44. (In Ukrainian).

9. Baieva 0.V. Menedzhment u haluzi okhorony zdorovia [Healthcare management]. Navch. posibnyk. K.: Tsentr uchbovoi literatury. 2008: 640. (In Ukrainian).

10. Constitution of Ukraine. 28.06.1996. (with changes). Vidomosti Verkhovnoi Rady Ukrainy. 1996; 30: 141. https://zakon.rada.gov.ua/ laws/show/254\%D0\%BA/96-\%D0\%B2\%D1\%80 (In Ukrainian)

11. Association Agreement between the European Union and the European Atomic Energy Community and their member states, of the one part, and Ukraine, of the other part. 2014. https://zakon.rada.gov.ua/laws/ show/984_011 (In Ukrainian).

12. Directive 2001/83/EC of the European Parliament and of the Council of 6 November 2001 on the Community code relating to medicinal products for human use. Official Journal of the European Communities EN. L 311/67. 2001:67-128. http://data.europa.eu/eli/dir/2001/83/oj.

13. Good pharmacy practice Joint FIP/WHO Guidelines on GPP standards for Quality of Pharmacy services. 2011. https://www.fip.org/file/1476.

14. On Medicines: The Law of Ukraine 04.04.1996, \# 123/96-VR (with changes). Vidomosti Verkhovnoi Rady Ukrainy. 1996; 22: 86. https:// zakon.rada.gov.ua/laws/show/123/96-\%D0\%B2\%D1\%80. (In Ukrainian).

15. Seniuta I. Y., Lyublinets 0. V. Medychnyi kodeks yak osnova v reformuvanni okhorony zdorovia Ukrainy [The Medical Code as the Basis of HealthCare Reform in Ukraine]. Ukrainskyi Medychnyi Chasopys Online. 2006; 3(53) 5-6. (In Ukrainian). 
ORCID and contributionship:

Lidiia H. Yurkovska: 0000-0002-2695-5433 A,B,D,E

Volodymyr V. Krasnov: 0000-0002-5967-9260 ${ }^{B, F}$

Serhii H. Ubohov: 0000-0002-9684-7323 E,F

\section{Conflict of interest:}

The Authors declare no conflict of interest.

\section{CORRESPONDING AUTHOR}

Lidiia H. Yurkovska

Shupyk National Medical Academy

of Postgraduate Education,

9 Dorohozhytska Str., 04112 Kyiv, Ukraine

tel:+380504183550

e-mail:postpostglossator@gmail.com

Received: 13.04 .2020

Accepted: 15.10 .2020

A - Work concept and design, B - Data collection and analysis, C - Responsibility for statistical analysis,

D-Writing the article, $\mathbf{E}$-Critical review, $\mathbf{F}$ - Final approval of the article 